\title{
POTENTIAL USE OF THE LIFE SATISFACTION APPROACH TO VALUE NONMARKET GOODS AND SERVICES
}

Cheryl Joy Fernandez, David Raitzer, and Edimon Ginting

NO. 569

January 2019
ADB ECONOMICS WORKING PAPER SERIES 


\section{Potential Use of the Life Satisfaction Approach to Value Nonmarket Goods and Services}

Cheryl Joy Fernandez, David Raitzer, and Edimon Ginting

No. 569 | January 2019
Cheryl Joy Fernandez (cjfernandez@up.edu.ph) is an Associate Professor at the University of the Philippines Visayas and a Visiting Fellow at the Asian Development Bank. Edimon Ginting (eginting@adb.org) is the Deputy Director General and David Raitzer (draitzer@adb.org) is an Economist at the Economic Research and Regional Cooperation Department, Asian Development Bank. 
(C) 2019 Asian Development Bank 6 ADB Avenue, Mandaluyong City, 1550 Metro Manila, Philippines

Tel +632632 4444; Fax +6326362444

www.adb.org

Some rights reserved. Published in 2019.

ISSN 2313-6537 (print), 2313-6545 (electronic)

Publication Stock No. WPS199912-2

DOI: http://dx.doi.org/10.22617/WPS199912-2

The views expressed in this publication are those of the authors and do not necessarily reflect the views and policies of the Asian Development Bank (ADB) or its Board of Governors or the governments they represent.

ADB does not guarantee the accuracy of the data included in this publication and accepts no responsibility for any consequence of their use. The mention of specific companies or products of manufacturers does not imply that they are endorsed or recommended by ADB in preference to others of a similar nature that are not mentioned.

By making any designation of or reference to a particular territory or geographic area, or by using the term "country" in this document, $A D B$ does not intend to make any judgments as to the legal or other status of any territory or area.

This work is available under the Creative Commons Attribution 3.0 IGO license (CC BY 3.0 IGO)

https://creativecommons.org/licenses/by/3.o/igo/. By using the content of this publication, you agree to be bound by the terms of this license. For attribution, translations, adaptations, and permissions, please read the provisions and terms of use at https://www.adb.org/terms-use\#openaccess.

This CC license does not apply to non-ADB copyright materials in this publication. If the material is attributed to another source, please contact the copyright owner or publisher of that source for permission to reproduce it. $\mathrm{ADB}$ cannot be held liable for any claims that arise as a result of your use of the material.

Please contact pubsmarketing@adb.org if you have questions or comments with respect to content, or if you wish to obtain copyright permission for your intended use that does not fall within these terms, or for permission to use the ADB logo.

Corrigenda to ADB publications may be found at http://www.adb.org/publications/corrigenda.

Notes:

In this publication, " $\$$ " refers to United States dollars.

$A D B$ recognizes "Russia” as the Russian Federation. 


\section{CONTENTS}

TABLES AND FIGURE

ABSTRACT

I. INTRODUCTION 1

II. THE ECONOMICS OF THE LIFE SATISFACTION APPROACH 5

III. $\quad$ METROPOLITAN ILOILO CASE STUDY 6
A. Data Collection

B. Model Specification 9

C. Summary Statistics 10

D. Regression Results $\quad 11$

E. Flood Valuation Estimates 13

$\begin{array}{ll}\text { IV. DISCUSSION } & 13\end{array}$

V. CONCLUSION

$\begin{array}{ll}\text { APPENDIX } & 17\end{array}$

$\begin{array}{lr}\text { REFERENCES } & 19\end{array}$ 


\section{TABLES AND FIGURE}

\section{TABLES}

$1 \quad$ Three Ways to Measure Subjective Well-Being 2

$2 \quad$ Other Factors Affecting Reported Life Satisfaction 8

3 Regression Variables 11

4 Results from First Stage Regression of Life Satisfaction against Listed Variables, 12 with "Threat to Safety" as the Instrument for "Flood Damage," Standard Errors Adjusted for Barangay Clusters $(n=392)$

$5 \quad$ Results from Second Stage Regression of Life Satisfaction against Listed Variables, Standard Errors Adjusted for Barangay Clusters ( $n=392)$

6 Selected Studies Using the Life Satisfaction Approach in Economic Valuation

FIGURE Growth of Subjective Well-Being Studies 


\begin{abstract}
Economic analysis often faces challenges in the valuation of nonmarket goods and services. The traditional set of nonmarket valuation tools for measuring Marshallian economic surplus has limitations related to potential bias in stated preferences and endogeneity of nonmarket amenity placement in revealed preference studies. The life satisfaction approach offers a Hicksian compensating variationbased alternative, which uses self-reported subjective well-being to calculate the marginal rate of substitution of income for nonmarket amenities or services. The conceptual basis for the approach is explained and illustrated with an example from Iloilo, Philippines. Recommendations are offered for future application of the technique in the economic analysis of investment projects.
\end{abstract}

Keywords: economic analysis, life satisfaction, natural disasters, Philippines, valuation, well-being JEL codes: D61, D69, D90, H40, Q51 


\section{INTRODUCTION}

The objective of economic analysis of public investments is to "ensure that scarce resources are allocated efficiently, and investment brings benefits to a country and raises the welfare of its citizens" (ADB 2017). An investment's effect on social welfare is conceptualized as the utility from changes in the supply and consumption of goods and services that the investment generates. For public services, that utility is usually conceived as a Marshallian consumer surplus (Marshall 1920), or the difference between willingness to pay (WTP), as reflected in a demand curve, and the actual price paid for total consumption of the good or service.

In the case of a marketed good or service in an undistorted market, marginal WTP is reflected in the equilibrium market price, and it is possible to infer the shape of the demand curve from observed changes in equilibrium prices and quantities demanded over time or space. For nonmarket goods and services, which do not have clearly defined prices and quantities, this is more difficult. In such cases, the demand curve may be traditionally approximated via a range of stated and revealed preference measures.

Stated preference measures attempt to ask hypothetical questions to either query WTP directly via contingent valuation methods or to ask for preferences between a series of alternatives structured so that WTP can be estimated econometrically. The limitation of stated preference methods is that answers, being nonbinding, suffer from hypothetical bias, because the responses condition intervention or service availability but not actual payment (Murphy et al. 2003). This means that there is often an incentive to overstate WTP.

Revealed preference methods attempt to recover WTP from actual behavior in markets that partially embed nonmarket amenities or services. These include travel cost methods that infer WTP from expenditures to reach environmental amenities, and hedonic property pricing that attempts to capture amenity values from higher property prices in proximity to nonmarket amenities. However, these methods often are plagued by problems of amenity endogeneity and simultaneity, which make it difficult to recover unbiased WTP (Sheppard 1998). These problems are compounded by conceptualization of property markets as more fluid and less affected by transaction costs than is often actually the case (Levinson 2018).

An alternative valuation possibility is to use Hicksian compensating variation (Hicks 1939) instead of Marshallian economic surplus to reflect economic benefits. The conceptual basis becomes the payment (income) that would be necessary to offset the problem or good or service that the investment is to improve, rather than an elicitation of WTP for the investment's services. If there is a means of relating utility to both income and the problem, it becomes possible to translate utility loss from the problem or good or service into an income equivalent, based on the marginal rate of substitution for income, without ever asking hypothetical questions of respondents or depending on hedonic models with endogeneity problems.

At the same time, application of such a technique depends on the ability to measure total beneficiary utility directly. Utility, as originally defined by Bentham (1970 [1780]), is a measure of individual well-being that reflects the individual's "hedonic quality of experience" (see, for example, Kahneman, Wakker, and Sarin 1997 for a discussion of Bentham's concept of utility, including the hedonic quality of experience). 
The challenge is that experience-based utility is not traditionally considered as objectively observable (Stutzer and Frey 2010). Utility extends beyond simple objective well-being indicators, which usually capture only a subset of indexes mechanistically, so that overall "happiness" is not directly reflected. Examples of these types of objective indicators include the Human Development Index, the Quality of Life Index, and the Sustainable Society Index.

A more complete measure of utility is offered by newer indexes of subjective well-being (SWB), which is the broad concept that refers to the cognitive and emotional self-evaluations of individuals about the quality of their lives. SWB is considered to be a measure of the quality of life of an individual or society (Diener, Oishi, and Lucas 2003). SWB includes intangible and subjective responses of individuals to likes (positives) and dislikes (negatives), feelings of joy or discontentment, satisfaction or dissatisfaction, and so forth. Diener (2006) succinctly defines SWB as the different types of self-evaluation, which are "reflective cognitive evaluations, such as life satisfaction and work satisfaction, interest and engagement, and affective reactions to life events, such as joy and sadness." According to Kahneman and Riis (2005) and Dolan, Peasgood, and White (2008), SWB can be generally measured through three broad categories (Table 1)-appraisal, experience, and eudaemonics-so that SWB scales can be measured by using either a single-item scale or multi-item scales.

Table 1: Three Ways to Measure Subjective Well-Being

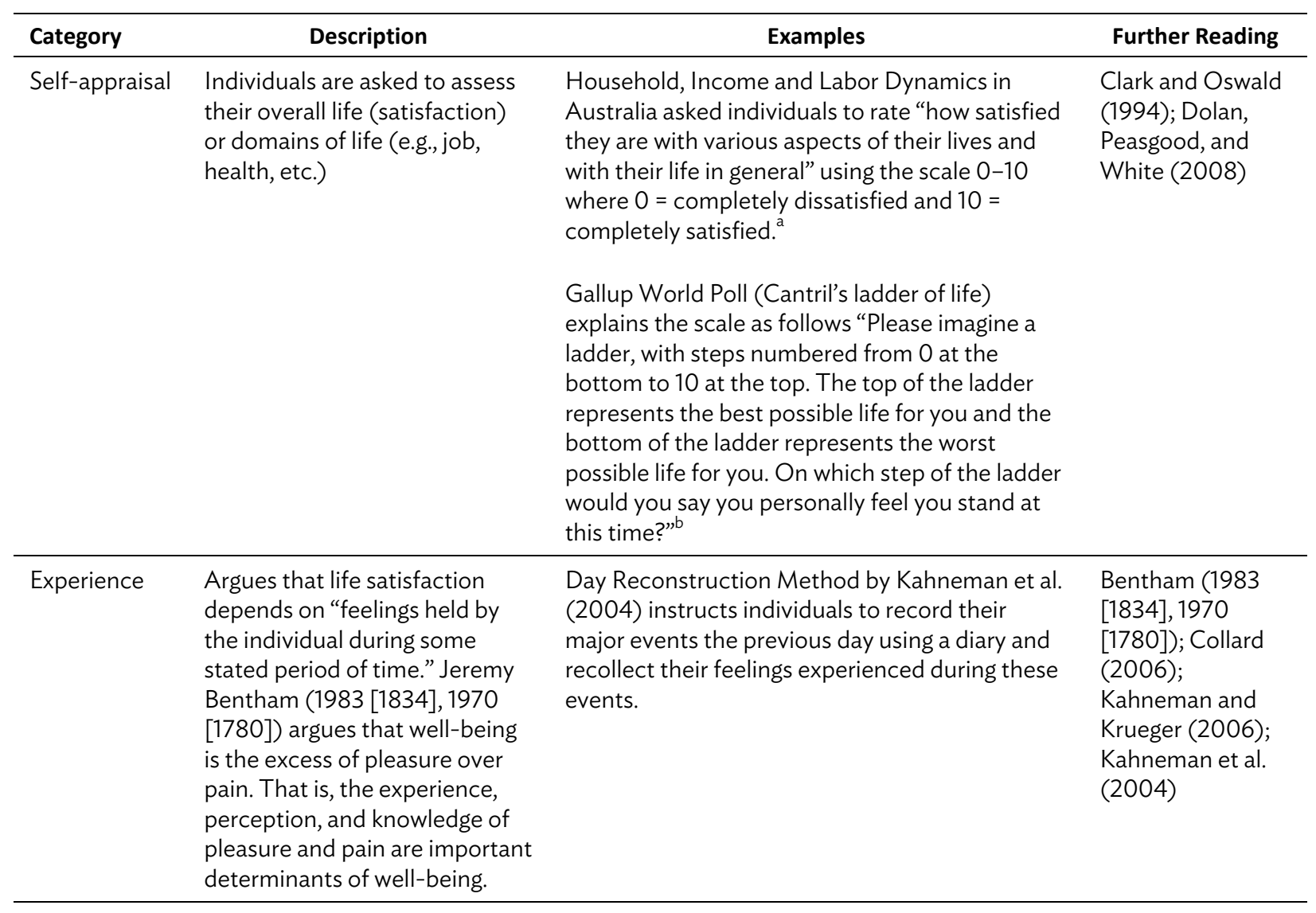


Table 1 continued

\begin{tabular}{|c|c|c|c|}
\hline Category & Description & Examples & Further Reading \\
\hline Eudaemonic & $\begin{array}{l}\text { Individuals share and evaluate } \\
\text { the meaning of their lives. } \\
\text { "Eudaemonia" in the } \\
\text { Aristotelian sense means a } \\
\text { human life that is actively full or } \\
\text { flourishing. Happiness means } \\
\text { living a full, active, and social } \\
\text { life. }\end{array}$ & $\begin{array}{l}\text { Inclusion of statements relating to depression } \\
\text { (dysfunctional energy and dysfunctional affect): } \\
\text { "how much time during the past month (scale of } \\
0-3 \text {, where } 3 \text { is all and } 0 \text { is none), the individuals } \\
\text { felt (1) full of life, ( } 2 \text { ) worn out, ( } 3 \text { ) tired, } \\
\text { (4) downhearted and blue, (5) calm and } \\
\text { peaceful, (6) nervous, ( } 7 \text { ) had a lot of energy, } \\
\text { and ( } 8 \text { ) were so down in the dumps that nothing } \\
\text { could cheer you up." (Ryff and Keyes 1995, } \\
\text { p. } 721 \text { ) }\end{array}$ & $\begin{array}{l}\text { Aristotle (1980), } \\
\text { Ryff (1989), } \\
\text { Hurka (1993), } \\
\text { White and Dolan } \\
\text { (2009), Bruni } \\
\text { (2010) }\end{array}$ \\
\hline
\end{tabular}

a Australian Institute of Family Studies. https://aifs.gov.au/publications/long-work-hours-and-wellbeing-fathers-and-their-famil/hildasurvey-and-measures.

b Gallup World Poll. https://news.gallup.com/poll/122453/understanding-gallup-uses-cantril-scale.aspx.

Sources: Compiled by authors from sources noted in the table; see the Reference section.

Other available SWB measures include life satisfaction (LS), the Happy Planet Index, and the Happiness Index. These indicators can be found in surveys or in various databases such as the World Database of Happiness, Eurobarometer Survey Series, World Values Survey (WVS), World Gallup Poll, German Socio-Economic Panel Study, and Urban Institute Ireland National Survey on Quality of Life. ${ }^{1}$

According to Dolan and White (2007), the number of SWB studies has grown significantly in the last 20 years. About 100 papers on SWB were published in 2001-2005 while EconLit only includes four published between 1991 and 1995. More recently, academic journals have emerged with a focus on well-being, such as the Journal of Happiness Studies, the Journal of Life Research, and Social Indicators Research (D'Acci 2011).

The figure below illustrates results of searches in the EconLit database with the following keywords: "life satisfaction," "happiness," "well-being," "wellbeing," "subjective well-being," and "subjective wellbeing." This figure shows a steadily rising trend of SWB research after Easterlin's work in 1974, and there is no sign of decline in recent years.

1 Database of Happiness. https://worlddatabaseofhappiness.eur.nl/; Eurobarometer Survey Series. https://www.gesis.org/eurobarometerdata-service/survey-series/; World Values Survey. http://www.worldvaluessurvey.org/wvs.jsp; World Gallup Poll. http://www.gallup.com/home.aspx; German Socio-Economic Panel Study. https://www.diw.de/en/diw_02.c.221178.en/about_soep.html; and Urban Institute Ireland National Survey on Quality of Life. http://www.ucd.ie/issda/. 


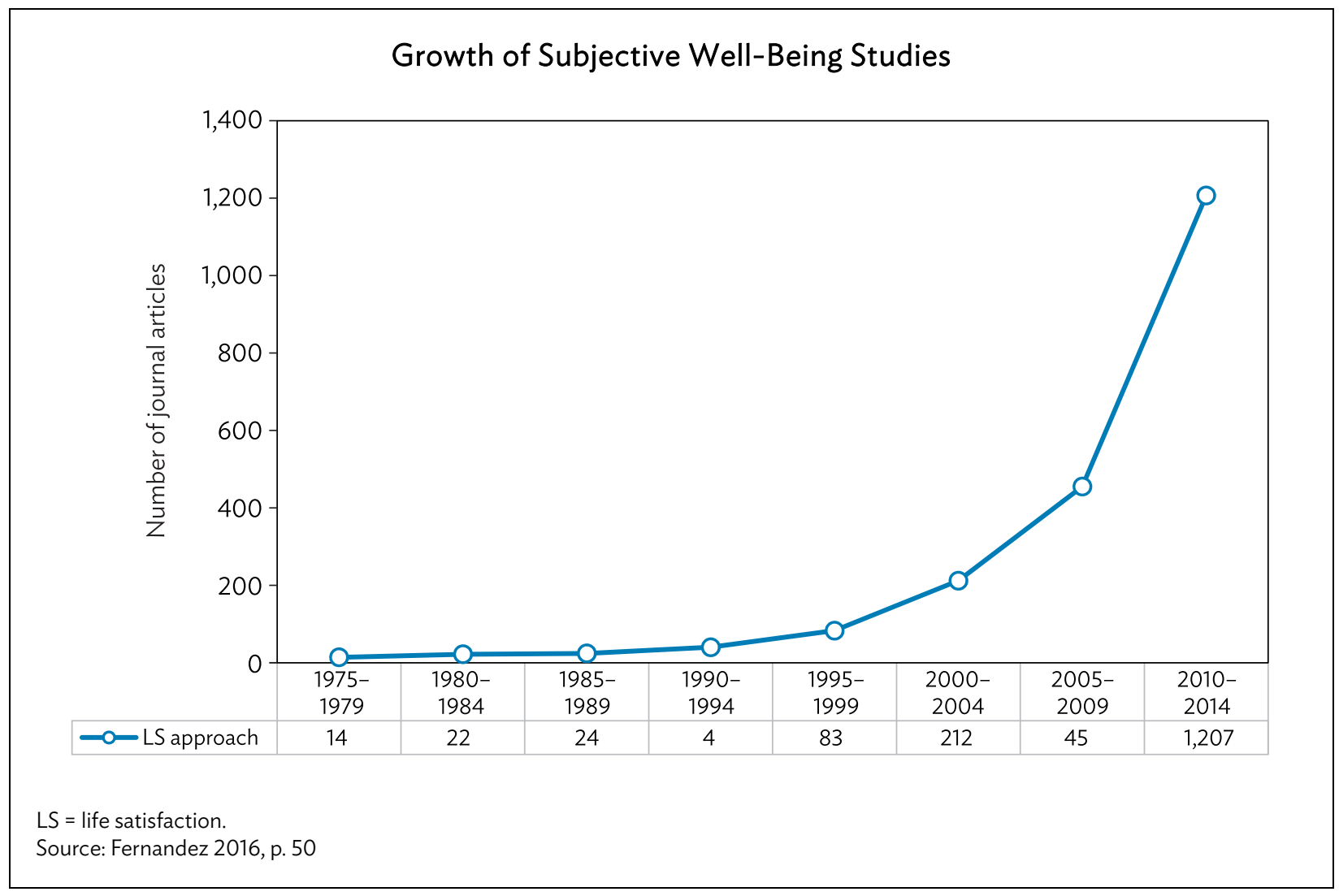

Despite extensive work on SWB, there have been challenges within the economics discipline on whether SWB measures (i.e., a single-item scale or multi-item scales) are psychologically valid (Diener, Inglehart, and Tay 2013; Jovanović 2016). A number of studies have examined these scales in terms of their reliability and validity.

Reliability means that items (that express life satisfaction) result in identical scores when administered under the same conditions (Diener, Inglehart, and Tay 2013). In their seminal work, Pavot and Diener (1993) claimed that the Satisfaction with Life Scale is a good "psychological construct" that measures respondents' overall assessment of their lives, using both social survey and clinical data. The results reflect that the LS scale has moderate temporal stability and autonomy. For example, in multi-item scales of the LS construct, items congregated and yielded 80-90 and higher Cronbach alphas (Diener, Diener, and Diener 1995; Eid and Diener 2004). In fact, there is a high correlation $(r=0.94)$ of responses between two independent global surveys-WVS, European Values Study, and the Gallup (Diener Inglehart, and Tay 2013), thus supporting the view that individuals answer the LS questions in a consistent manner.

A valid scale is one that the respondent understands and to which he or she relates (Stutzer and Frey 2010). Psychological data, which are not reported by participants, such as moods and emotions, have been found to be associated with reported LS scores (Sandvik, Diener, and Seidlitz 1993; Steptoe, Pollard, and Wardle 1995; Seligman and Csikszentmihalyi 2014). Diener, Inglehart, and Tay (2013, p. 508) observed that "self-report scales correlate with each other and with other types of measures of well-being that do not depend on reports by the respondents." In the global WVS, 98\% of the survey participants answered the question relating to LS, which also suggests the validity of SWB measures. 
SWB can also be used for interpersonal comparison (Kristoffersen 2010). Kahneman, Wakker, and Sarin (1997), for example, found that experience-based utility (such as self-reported satisfaction) empirically converged with choice-based outcomes. This implies that SWB measures may be compared across individuals. From initial uncertainty about whether SWB is a cardinal or an ordinal measure, increasing evidence has emerged that indicates SWB can be cardinally measured. This assumption is critical, as it enables corresponding quantitative analysis to be used. Kristoffersen (2010) reported that most SWB studies do not specify their assumptions relating to cardinality. Research, such as that of Easterlin (1974) and Veenhoven (1995), used aggregates and averages to reflect cardinality. Kristoffersen (2010) reviewed SWB literature relating to cardinality and concluded that cardinality is strong among empirical SWB studies. This is further supported by other studies, e.g., Diener et al (1999); Frey and Stutzer (2002); Di Tella, MacCulloch, and Oswald (2003); Dolan, Peasgood, and White (2008); and Kahneman (1999). Moreover, these empirical works are representative, usually involving large-scale samples, across countries or cultures or regions. Thus, the growth of this literature during recent decades has provided evidence that SWB is increasingly recognized as a valid, reliable, and stable measure of individual welfare.

This paper presents a case study to demonstrate that people's preferences may be captured using the life satisfaction approach (LSA), so as to determine the monetary value of nonmarket factors and services. An increasing focus of public investments is on nonmarket amenities and services, such as public amenities and environmental protection. As this paper demonstrates, the LSA can enable the values of these types of investments to be quantified in new ways, so as to inform analysis of their social value.

This paper has five sections, wherein these sections develop systematically the paper's argument that LSA is a potential complementary method for valuing services not traded in markets. Section I defines the challenges faced in valuation of nonmarket benefits within investment economic analysis and the limitations of traditional methods. Section II introduces LSA as an approach to economic analysis using Hicksian compensating variation; while section III presents a case study of how the LSA can be used in valuing flood control, a regulating ecosystem service in Metropolitan Iloilo, central Philippines. This is one of the first studies that uses self-reported satisfaction and flood damage for quantifying the value of flood prevention initiatives in the Philippines. Sections IV and $V$ discuss the requirements and limitations of the methodology, and its scope for further application and conclusion, respectively.

\section{THE ECONOMICS OF THE LIFE SATISFACTION APPROACH}

\section{The Life Satisfaction Model}

Assuming that SWB is a true measure of utility, the LSA, an evaluative measure of SWB, determines the value of nonmarket goods and services (e.g., environmental degradation) by examining how they affect the individual's self-reported LS (Fujiwara and Campbell 2011). The LSA assumes that utility can be measured cardinally and directly:

$$
u=(C, Q)
$$

where, $C$ represents any market good/service and $Q$ represents a nonmarket good or service. 
With a cross-sectional dataset, one can postulate the following regression model of LS:

$$
L S_{i}=\alpha+\beta_{1} \ln \left(y_{i}\right)+\beta_{2} \ln Q_{i}+\beta_{3} Z_{i}+\varepsilon_{i}
$$

where, $L S_{i}$ is the stated LS of individual $i$-assumed to represent utility, $y_{i}$ is the income of individual $i, Q_{i}$ corresponds to the level of nonmarket goods consumed by individual $i, Z_{i}$ is a vector of characteristics associated with individual $i$ that may influence LS, and $\varepsilon_{i}$ is an error term.

An enumerator of a survey can query LS by directly asking each person to give a "mental account of his or her own utility" (Dolan and Metcalfe 2008, Ferreira and Moro 2010). Examples of such measures were presented earlier in Table 1. As mentioned before, an appraised SWB may be measured using a single-item scale or a multi-item scale. The German Socio-Economic Panel World Values Survey and many other nationally representative global surveys use single-item scales due to their conciseness and ease of use (Jovanović 2016). The Satisfaction with Life Scale is also a known and most favored multi-item LS survey (Diener, Inglehart, and Tay 2013). Researchers who used the latter aggregated or averaged the scores for each item to derive mean LS scores.

Income is typically specified in logarithmic form to reflect the diminishing marginal effect of income on life satisfaction, and to assume that the monetary equivalent of nonmarket goods and services (e.g., environmental conditions) is a fraction of income (Stutzer and Frey 2010). The specification allows for the fact that poor individuals are willing to give up less (absolute) income for an improvement of environmental conditions compared with rich individuals. The set of factors influencing individual LS can be both at micro (e.g., education, family relations) or macro (e.g., inflation rate) levels. For example, good mental health conditions (e.g., ascertained using Mental Health Section of the open questions, affirmation, reflective listening, and summary reflections Multidimensional Functional Assessment Questionnaire and Composite International Diagnostic Interview) and high level of overall quality of health (e.g., by using reported health condition, Likert scale, "1=worst, $5=$ excellent") are negatively correlated with SWB (Johnson et al. 1988, Fergusson et al. 2015, Garcia et al. 2017). Dolan, Peasgood, and White (2008) summarize the typical determinants of individual LS, and the Appendix of this paper provides a guide to additional reading about these factors. Equation (2) can be estimated as various types of regressions-e.g., ordered discrete choice, ordinary least square (Stutzer and Frey 2010)-in order to estimate welfare estimates.

When dealing with natural logarithmic forms of income and environmental goods, a Hicksian welfare measure is appropriate. Following Ambrey and Fleming (2014), Ferreira and Moro (2010), and Welsch (2006), compensating surplus (CS) can be calculated using the formula below.

$$
C S=-\exp \left[\ln (\bar{y})+\frac{\widehat{\beta}_{2}}{\widehat{\beta}_{1}}\left(\ln \left(Q_{1}\right)-\ln \left(Q_{2}\right)\right)\right]+\bar{y}
$$

Here, $Q_{1}$ and $Q_{2}$ are the initial and new levels of nonmarket goods, respectively.

\section{METROPOLITAN ILOILO CASE STUDY}

Flood valuation provides a useful example of the difference between the LS approach and conventional valuation procedures. This is so because the typical approach is concrete and relatively consistent, compared with other nonmarket amenities or services. The typical approach consists of 
estimation of a flood loss curve, which relates return periods (event frequencies) to the magnitudes of losses, following a curve that typically demonstrates a convex relationship between damage and return periods. The losses are typically defined as the values of assets lost, such as damage to structures, lost agricultural output and household goods damaged in previous events that align with specific return periods. The loss curve without a flood control project is compared with the loss curve with such a project, and the area between the curves represents economic benefits of the project. However, this approach misses the value to the beneficiaries of not experiencing flooding. The LSA provides a potential option for capturing these additional benefits.

Flood control is especially relevant in the Philippines. According to the World Risk Report, the Philippines is the second most climate-vulnerable country (UNU-EHS 2014), behind only Vanuatu. Metropolitan Iloilo (MI) in central Philippines was taken as a case in point in view of its inherent disaster vulnerability and diverse sociodemographic characteristics. Specifically, the MI region is natural disaster prone because of its location (i.e., western part of the Philippines) and its low-lying topography. Residents experience typhoons and floods, which usually come from its three major rivers (Iloilo River, Jaro River, and Batiano Rivers) and from its coast (Iloilo-Guimaras Strait). Moreover, the economic and development situation of the region has also contributed to the vulnerability of residents. The MI region has experienced rapid infrastructure (e.g., industrial developments in Mandurriao District in Iloilo City) and residential development (e.g., real estate developments in Pavia, Oton, and Sta. Barbara) for the past 5 years, which subsequently increased migration to the city center. Moreover, hundreds of households who illegally reside in the riverbanks were also heavily impacted during floods and were regularly evacuated from these areas. The sampling of MI residents allowed inclusion of various levels of socioeconomic characteristics and levels of disaster impact.

\section{A. Data Collection}

Sampling. The case study area comprises urban Iloilo City and six nearby towns (Cabatuan, Leganes, Oton, Pavia, San Miguel, and Santa Barbara). Multistage sampling was performed. First, all towns and the city were selected. Second, geographical sampling was done by dividing the area into 33 equal geographic grids, wherein one 'typical' barangay was purposively selected from each grid. Next, 16 residents from each of the 29 town barangays and 34 residents from each of the four lloilo City barangays were convenience sampled, for a total of 600 respondents. To obtain consistent flood damage estimates, observations from the 392 respondents who had lived in the same area for the last 5 years were used.

Questionnaire design. A mental assessment of one's overall LS (Dolan, Peasgood, and White 2008) can be queried using a single question or a composite of questions (Veenhoven 2014). In the survey instrument applied, SWB was elicited using the question "Overall, how would you rate your satisfaction with life?" The question was posed in the local dialect (Hiligaynon). Responses were noted on a scale of 100 (very satisfied) to 0 (least satisfied). The validity and reliability of the question was tested using results from six focus group discussions and 50 pretest surveys.

Flood prevention strategies have potential for reducing flood damages of residents. Heterogeneity (i.e., households in the same locality might experience different impacts from floods) may be a problem when comparing self-reported well-being and secondary data (e.g., national or regional agricultural loss data, flooding vulnerability, etc.). Estimates of problem intensity or exposure from secondary location-based data may mask important variation among affected households. There 
are various ways to deal with the problems of heterogeneity, e.g., MacKerron and Mourato (2009) use distance from an urban center, and Ferreira et al. (2013) use distance from an air monitoring system.

In this case, to provide household-level estimates, flood damage data were elicited from individuals using a set of questions about their flood experiences. Specifically, respondents were asked to identify various flood incidences they had experienced and the corresponding damage they incurred for each flood. Monetary damage was estimated for various damage types: damage to agricultural crops and other personal properties, employment losses, and additional damage (e.g., purchase of clean water during floods, medicine, etc.). A five-point scale $(0=$ not threatened to $4=$ most threatened) was also used to measure the level of threat experienced. Another limitation of many prior flood valuation studies is that assessments cover one-off flood incidences rather than the impact across years of flood experience (van der Veen 2004). In effect, the long-term effects of floods are not fully captured. To address this, flood incidences and damage were asked for the last 5 years, in order to capture the impact of recurrent flood events and were then aggregated. In effect, the aggregated threat scale is a composite index ranging from 0 to 20 , with all integer values in between as possible values.

Factors other than flood damage that have been found to influence self-reported satisfaction include gender, education, age, number of children, household size, employment, income, health, faith, and public infrastructure (see sources cited in Table 2). The survey was designed to capture these variables.

\section{Table 2: Other Factors Affecting Reported Life Satisfaction}

\begin{tabular}{ll}
\hline Factor & Sales are happier than females (Sarracino 2013; Helliwell and Putnam 2004). \\
\hline Gender & Gender is not a significant factor (MacKerron and Mourato 2009; Cramm, Møller, and \\
& Nieboer 2012; Kahneman and Krueger 2006). \\
& The higher the level of education attained, the higher the level of LS (Blanchflower and \\
& Oswald 2004, Ferrer-i-Carbonell and Frijters 2004). \\
Education & Education is insignificantly correlated with LS (Rehdanz and Maddison 2005). \\
& The relationship is U-shaped i.e., LS is highest among the young (Terano and Mohamed \\
& 2014, MacKerron and Mourato 2009) and the old (Blanchflower and Oswald 2004; Dolan, \\
Age & Peasgood, and White 2008). \\
& Age is not a significant factor in LS (Cramm, Møller, and Nieboer 2012). \\
& More children results in lower LS (Di Tella, MacCulloch, and Oswald 2003; Blanchflower and \\
& Oswald 2004). \\
Employment has a positive impact on overall LS (Clark and Oswald 1994, Sarracino 2013). & Higher income means higher LS scores (Dolan, Peasgood, and White 2008; Easterlin 1995; \\
Employment & Helliwell and Putnam 2004). \\
Income & Positive LS effects derive from good health (MacKerron and Mourato 2009), strong faith \\
Health, faith, and public & (Helliwell 2003), and good public infrastructure such as roads (Arifwidodo and Perera 2011). \\
\hline infrastructure &
\end{tabular}

LS = life satisfaction.

Source: Compiled by authors from sources noted in the table; see the Reference section. 


\section{B. Model Specification}

As mentioned earlier, the LSA method estimates the value of nonmarket goods by estimating how they impact reported SWB (Fujiwara and Campbell 2011). The approach has been shown to be a serviceable proxy for utility (Kristoffersen 2010) at both microeconomic (Ferreira and Moro 2010) and macroeconomic (Di Tella, MacCulloch, and Oswald 2003) levels. LS is normally measured by asking individuals to provide a mental account of their utility (Dolan, Peasgood, and White 2008), which includes self-valuations of their positive and negative experiences (Kahneman and Krueger 2006).

This study uses an ordinary least squares specification to estimate the regression model of equation (2), which is in line with most LSA studies (Ferrer-i-Carbonell and Frijters 2004, MacKerron 2012). Other types of regressions used in LSA studies were ordered probit and logit for ordinal LS comparability (MacKerron and Mourato 2009; Gong, Cassells, and Keegan 2011; Sarracino 2013; Luechinger and Raschky 2009). However, the outcomes of models that assume cardinality and those that do not are similar (Ferrer-i-Carbonell and Frijters 2004). Flood damage estimates (both absolute and relative) and income were analyzed in logarithmic forms to capture the diminishing marginal nature of damage and income.

The endogeneity of income and flood damage to the self-reported LS scores was tested independently using a Durbin-Wu-Hausman test. Income was not found to be endogenous, but flood damage was. This may be because self-reported flood damage has potential problems of measurement error, or it may be because of simultaneity of flood damage and income if poorer people have more flood exposure.

Various combinations of sociodemographic characteristics (e.g., the number of different income sources, employment status, age, education, size of household) were compared as potential instrumental variables. Tests showed that perceived "threat to safety" (discussed in section III.D) is the strongest and most appropriate instrumental variable for flood damage. As an instrument, "threat to safety" is relevant and satisfies the exclusion restriction. The instrument is relevant, as flood threat correlates with flood exposure (i.e., threats to personal safety and safety of others increases when flood damages are high). This is confirmed by a high partial $R^{2}$ and significant $F$-test statistic for the first stage regression.

The instrument satisfies the exclusion restriction because perceived threat as a transitory phenomenon does not affect long-term life satisfaction directly. Risk attitudes depend on individual perceptions on potential losses or benefits (Grothmann and Pat 2005; Botzen, Aerts, and Van den Bergh 2013). For example, an increase in threat safety perception, ceteris paribus, would decrease flood damages, as the highly risk averse would seek to avoid potential exposure. These individuals overestimate possible losses, and this limits their loss probabilities (Cha and Ellingwood 2012), especially when confronted by disasters that likely result to physical injuries. Risk averse decision makers avoid floods in many ways, such as: elevation (Botzen, Aerts, and Van den Bergh 2013); evacuation (Walch 2018; Lim, Lim, and Piantanakulchai 2016); and flood insurance (Cha and Ellingwood 2012; Lamond, Proverbs, and Hammond 2009; Oulahen 2015).

Lazarus and Folkman (1984, as cited in Matthieu and Ivanoff 2006) argue that "psychosocial stressor is cognitively interpreted along a continuum ranging from no harm to adversely affecting the individual's well-being." Individuals respond to stressful life events differently and that they have different perceptions of growth and positivity of life (Park and Helgeson 2006; Park 2010; Tugade, 
Fredrickson, and Barrett 2004). A comprehensive literature review of Linley and Stephen (2004) on adversarial growth has found out that perceived benefits and harm are positively correlated with growth, but not consistently associated with trauma. Thus, some individuals who underwent adversities (such as floods) will not necessary experience notable mental or physical health consequences (such as trauma) (McMillen, Smith, and Fisher 1997), which may in turn affect their overall well-being.

The empirical two-stage model thus becomes:

$$
Q_{i}=\alpha+\beta_{1} W_{i}+\eta_{i}
$$

where $Q_{i}$ is the level of flood damage reported, $W_{i}$ is the perceived threat to safety, $\eta_{i}$ is an error term in the first equation to instrument damage in the first stage and for the second stage:

$$
L S_{i}=\alpha+\beta_{1} y_{i}+\beta_{2} \widehat{Q}_{i}+\beta_{3} Z_{i}+\mu_{i}
$$

where $L S_{i}$ is the stated LS of individual $i, y_{i}$ is the income of individual $i, \widehat{Q}_{i}$ corresponds to predicted flood damage, set $Z_{i}$ is a vector of characteristics associated with individual $i$ that may influence LS, and $\mu_{i}$ is an error term in the second-stage equation.

Inclusion of many predictors can complicate estimating the effect of income on LS (Carroll, Frijters, and Shields 2009). Stepwise regression can be used to identify determinants that exhibit strong association with LS, and it can eliminate factors that have no or weak relationship to LS. Thus, 12 factors (flood damage, years of education, gender, age, number of children in the household, secure employment, insecure employment, no employment, income, health status, religion, good road conditions) were tested using stepwise forward regression with a minimum p-value of 0.30 , following the approach of Galinha and Pais-Ribeiro (2011). Only nine variables were used in the final LS regressions- predicted flood damage, years of education, age, number of children in the household, no employment, income, health status, religion, and good road conditions. Multicollinearity was also tested between these determinants using variance inflation factors. Predictors had variance inflation factors ranging from 1.07 to 1.4 , signifying that multicollinearity is not a problem.

The coefficients from income and predicted flood damage were used to estimate the amount needed to compensate for changes in flood damage at the same level of LS. From this, the value of flood prevention is calculated by multiplying the income compensation with the average flood damage experienced.

Standard errors were adjusted for heteroskedasticity and for clustering at the barangay level (Moulton 1990). The sample allowed for a possibility that predicted flood damages are uncorrelated across clusters but may be correlated within clusters. Adjustments of standard errors for clustering has been done in LS research, for instance, by MacKerron and Mourato (2009), Ferreira and Moro (2010), Ambrey and Fleming (2014).

\section{Summary Statistics}

Descriptive statistics (mean and standard deviation) for variables used in the final LS model are presented in Table 3. The respondents' average LS score was 66, suggesting they were moderately satisfied with their lives. The table shows that the average monetary damage for the last 5 years of 
floods were approximately $\$ 429$ per household (or $\$ 86$ per year). ${ }^{2}$ The estimate is low, as expected, compared to the one-off flood damage estimates in Bangladesh ( $\$ 190-\$ 200$ per household [Brouwer et al. 2009]) and in Viet Nam (\$935 per household [Bui and Nguyen 2014]).

Table 3: Regression Variables

\begin{tabular}{|c|c|c|c|}
\hline Variable & Description & Mean & Std. Dev. \\
\hline $\begin{array}{l}\text { Life satisfaction (LS), } \\
\text { dependent variable }\end{array}$ & Self-reported LS: 0 = least satisfied; $100=$ most satisfied & 66.0 & 18.2 \\
\hline $\begin{array}{l}\text { Flood damage (In, US } \\
\text { dollars) (endogenous) }\end{array}$ & $\begin{array}{l}\text { Natural log of all self-reported monetary flood damage incurred in the } \\
\text { span of } 5 \text { years }\end{array}$ & 4.7 & $1,086.6$ \\
\hline Education (years) & Respondent's years of formal education & 9.7 & 3.0 \\
\hline Age & Age of respondent, in years & 47.0 & 153.0 \\
\hline Children (number) & Children living in respondent's household & 0.8 & 0.4 \\
\hline Unemployment status & A measure of employment status: $1=$ unemployed; $0=$ otherwise & 0.2 & 0.4 \\
\hline Income (In, US dollars) & $\begin{array}{l}\text { Natural log of yearly income, calculated using food grown at home and } \\
\text { adjusted for economies of scale at home (number of working adults) }\end{array}$ & 9.8 & $1,675.3$ \\
\hline In good health & $\begin{array}{l}\text { From a 5-point Likert statement: "I am in good health"; } 1 \text { = "strongly } \\
\text { disagree"; } 5 \text { = "strongly agree" }\end{array}$ & 1.7 & 1.0 \\
\hline Committed to one's faith & $\begin{array}{l}\text { Total scores from a 5-point Likert statement: "I am committed to my } \\
\text { faith": } 1 \text { = "strongly disagree"; } 5 \text { = "strongly agree" }\end{array}$ & 1.2 & 0.6 \\
\hline Good roads & $\begin{array}{l}\text { Total scores from a 5-point Likert statement: "Roads in my } \\
\text { neighborhood are in good condition": } 1 \text { = "strongly disagree"; } 5 \text { = } \\
\text { "strongly agree" }\end{array}$ & 3.4 & 1.6 \\
\hline Threat to safety & $\begin{array}{l}\text { Total scores of all flood incidences identified by the respondents from } \\
\text { a 5-point Likert question," During the floods, was your life or safety } \\
\text { threatened and/or that of close friends or family?" }\end{array}$ & 3.0 & 3.2 \\
\hline
\end{tabular}

US = United States.

Source: Authors' calculations.

\section{Regression Results}

To determine the value of flood prevention, the LS regression was executed using the model specifications and the determinants discussed in the previous section. Tables 4 and 5 present the results of the first stage regression and the findings of the second stage regression.

As mentioned earlier, monetary flood damage was found to be endogenous and the instrumental variable "threat to safety" was used. The instrument is a continuous index variable as it is measured as aggregate levels of threats from the flood incidences. The instrument was found to be highly significant-F-statistics $=70.2$ (Table 4 ). The average threat score was 2.95 , with a standard deviation of 3.2.

$2 \quad \ln 2015, \$ 1=$ Php 45 . 
Table 4: Results from First Stage Regression of Life Satisfaction against Listed Variables, with "Threat to Safety" as the Instrument for "Flood Damage," Standard Errors Adjusted for Barangay Clusters ( $n=392)$

\begin{tabular}{ll}
\hline Determinant & Result \\
\hline Flood damage (In, US dollars) (endogenous) & $R^{2}=0.4207$ \\
& Partial $R^{2}=0.358$ \\
& Adjusted $R^{2}=0.407$ \\
& Robust $(1,382)=29.862(0.000)^{* * *}$ \\
& Endogeneity tests \\
& Durbin (score) chi $^{2}=5.844(0.022)^{* *}$ \\
\hline
\end{tabular}

US = United States

Note: ${ }^{*} p<0.10 ;{ }^{* *} p<0.05 ;{ }^{* *} p<0.001$.

Source: Authors' estimates.

In Table 5, the significant variables are overall income, faith, age, well-being, road infrastructure, health, and number of children in the household. The directions of relationships concur with previous studies, including those from less developed areas. More importantly, income and predicted flood damage have positive and negative associations with the level of LS, as expected. This indicates that the LS model is robust and coefficients of income and flood damage may be used for valuation.

\section{Table 5: Results from Second Stage Regression of Life Satisfaction against Listed Variables,} Standard Errors Adjusted for Barangay Clusters $(n=392)$

\begin{tabular}{|c|c|}
\hline Determinants of Self-Reported Satisfaction Scores & Coefficients (Robust Standard Errors) \\
\hline Income (In) & $\begin{array}{l}2.540^{* * *} \\
(0.872)\end{array}$ \\
\hline Good roads & $\begin{array}{l}1.382^{* *} \\
(0.712)\end{array}$ \\
\hline Children & $\begin{array}{l}-4.161^{* *} \\
(1.987)\end{array}$ \\
\hline Committed to one's faith & $\begin{array}{r}--2.672^{*} \\
(1.848)\end{array}$ \\
\hline Flood damage (In) (endogenous, instrumented) & $\begin{array}{l}-1.139^{* *} \\
(0.480)\end{array}$ \\
\hline Good health & $\begin{array}{l}-1.660^{*} \\
(1.085)\end{array}$ \\
\hline Age & $\begin{array}{c}0.133^{* *} \\
(0.060)\end{array}$ \\
\hline Education & $\begin{array}{c}0.244 \\
(0.308)\end{array}$ \\
\hline Unemployment & $\begin{array}{l}3.247 \\
(1.99)\end{array}$ \\
\hline Constant & $\begin{array}{l}42.449^{* * *} \\
(10.609)\end{array}$ \\
\hline$R^{2}$ & 0.0688 \\
\hline
\end{tabular}

Notes: With "Threat to Safety" used as the Instrument for "Flood Damage," standard errors adjusted for barangay clusters. Numbers in parentheses show standard errors. ${ }^{*} p<0.10$; ${ }^{* *} p<0.05$; ${ }^{* * *} p<0.001$.

Source: Authors' estimates. 


\section{E. Flood Valuation Estimates}

As illustrated in section II, it is possible to calculate the value of floods (in this case reduction of flood damage) using the coefficients of income $\left(\beta_{1}\right)$ and flood damage $\left(\beta_{2}\right)$. The value is the amount of income that needs to be compensated, in order to retain the same level of LS when flood damage occurs. Following equation (3), the mean implicit WTP in terms of yearly household income for the elimination of flood damage is equivalent to $\$ 144$, which is considerably higher than the direct loss of $\$ 86$. This suggests that there is a substantial loss of utility from flooding beyond the direct damages encountered.

Unfortunately, there is no study that could be used to benchmark these estimates. The only LSA study on flooding to date is that of Luechinger and Raschky (2009), which used national-level flood data across countries and found that $23 \%$ of annual income is required to compensate for flood risk. In comparison, the lloilo estimate is only $4.4 \%$ of the residents' average annual income. The difference may be due to the studies' scopes, as the latter assessed recurring flood damage (using selfreported flood damage) while the former examined the frequency of flood incidences (using secondary data).

\section{DISCUSSION}

The Iloilo case study reflects only one example among many LSA applications for valuation of nonmarket benefits. Although the example pertains to disaster risk reduction, most other studies pertain to other types of benefits. The other LSA applications have pertained to such issues as air pollution, noise pollution, green space, power preferences, and security (Table 6). A common characteristic of most studies is that the values identified are higher than those using other techniques, but are still within the range of values in previous literature.

Table 6: Selected Studies Using the Life Satisfaction Approach in Economic Valuation

\begin{tabular}{|c|c|c|c|}
\hline Study & Location & Good or Service & Value \\
\hline Welsch (2002) & 54 countries & $\begin{array}{l}\text { Air pollution } \\
\left(\mathrm{NO}_{2}\right)\end{array}$ & $\$ 0.07$ per ton of $\mathrm{NO}_{2}$ \\
\hline \multirow{3}{*}{$\begin{array}{l}\text { Tsurumi and } \\
\text { Managi (2015) }\end{array}$} & \multirow{3}{*}{$\begin{array}{l}\text { Lanto and } \\
\text { Kansai in Japan }\end{array}$} & \multirow[t]{3}{*}{ Green spaces } & Marginal WTP for a $1 \%$ increase in green space: \\
\hline & & & $\begin{array}{l}\text { Average green coverage rate for } 100 \mathrm{~m}-300 \mathrm{~m} \text { is } 14.73 \% \text { of } \\
\text { income }\end{array}$ \\
\hline & & & $\begin{array}{l}\text { Average green coverage rate for } 300 \mathrm{~m}-500 \mathrm{~m} \text { is } 18.25 \% \\
\text { of income }\end{array}$ \\
\hline \multirow[t]{4}{*}{$\begin{array}{l}\text { Ambrey and } \\
\text { Fleming (2014) }\end{array}$} & \multirow[t]{4}{*}{ Australia } & \multirow[t]{4}{*}{ Protected areas } & $\begin{array}{l}\text { Implicit WTP, in terms of household income, } 1 \% \text { increase in } \\
\text { the extent of protected areas: }\end{array}$ \\
\hline & & & Wilderness area $(\$ 2,950)$ \\
\hline & & & Natural monument or feature $(\$ 6,650)$ \\
\hline & & & Habitat and Species Management Area $(\$ 9,650)$ \\
\hline Santos (2013) & UK & Domestic violence & $£ 27,000-£ 70,000$ \\
\hline Luechinger (2009) & Germany & $\begin{array}{l}\text { Air pollution } \\
\left(\mathrm{SO}_{2}\right)\end{array}$ & $\begin{array}{l}\text { Value for marginal improvement in } \mathrm{SO}_{2} \text { concentrations is } \\
€ 173-€ 313\end{array}$ \\
\hline $\begin{array}{l}\text { Menz and Welsch } \\
\text { (2010) }\end{array}$ & $\begin{array}{l}25 \mathrm{OECD} \\
\text { countries }\end{array}$ & $\begin{array}{l}\text { Air pollution } \\
\left(\mathrm{PM}_{10}\right)\end{array}$ & $\begin{array}{l}\text { Marginal WTP is } \$ 110-\$ 188 \text { per microgram per cubic } \\
\text { meter of PM } 10\end{array}$ \\
\hline
\end{tabular}


Table 6 continued

\begin{tabular}{|c|c|c|c|}
\hline Study & Location & Good or Service & Value \\
\hline \multirow[t]{2}{*}{$\begin{array}{l}\text { Frey, Luechinger, } \\
\text { and Stutzer (2009) }\end{array}$} & \multirow[t]{2}{*}{$\begin{array}{l}\text { France and the } \\
\text { British Isles }\end{array}$} & \multirow[t]{2}{*}{ Terrorism } & $\begin{array}{l}\text { Resident of Northern Ireland-about } 26 \% \text { (fatalities) and } \\
37 \% \text { (incidents) of his or her income }\end{array}$ \\
\hline & & & $\begin{array}{l}\text { Resident of Paris-about } 4 \% \text { (fatalities) and } 8 \% \text { (incidents) } \\
\text { of his/her income }\end{array}$ \\
\hline \multirow{3}{*}{$\begin{array}{l}\text { Kuehnle and } \\
\text { Wunder (2016) }\end{array}$} & \multirow{3}{*}{$\begin{array}{l}\text { Germany and } \\
\text { the UK }\end{array}$} & \multirow{3}{*}{$\begin{array}{l}\text { Daylight Saving } \\
\text { Time (DST) }\end{array}$} & Value of DST (first week after DST) \\
\hline & & & $\begin{array}{l}\text { Germany-increase of } 10 \% \text { in household income to hold LS } \\
\text { constant }\end{array}$ \\
\hline & & & $\begin{array}{l}\text { UK-increase of } 34 \% \text { in household income to hold LS } \\
\text { constant }\end{array}$ \\
\hline $\begin{array}{l}\text { Kountouris and } \\
\text { Remoundou (2011) }\end{array}$ & $\begin{array}{l}\text { Mediterranean } \\
\text { region }\end{array}$ & Forest fires & $\begin{array}{l}\text { Monetary loss from an additional fire incident per } \\
\text { household to be } € 0.20 \text { and the loss from burning an } \\
\text { additional } 100 \text { hectares of forest at } € 2.03 \text {, respectively }\end{array}$ \\
\hline $\begin{array}{l}\text { van Praag and } \\
\text { Baarsma (2005) }\end{array}$ & Amsterdam & Noise pollution & $\begin{array}{l}\text { Compensation for noise increase from } 20 \text { to } 30 \mathrm{Ku} \text {-band is } \\
\text { about } 24 \% \text { of income ( } € 33.6 \text { per month) for households } \\
\text { with monthly net income of } € 1,500\end{array}$ \\
\hline $\begin{array}{l}\text { Welsch and } \\
\text { Biermann (2014) }\end{array}$ & Europe (20) & $\begin{array}{l}\text { Electricity supply } \\
\text { preferences }\end{array}$ & $\begin{array}{l}1 \text { percentage point substitution of gas-based electricity for } \\
\text { nuclear power is equivalent to an increase in household } \\
\text { income by } € 790 \text { per year }\end{array}$ \\
\hline $\begin{array}{l}\text { Anderson et al. } \\
(2016)\end{array}$ & Beijing & $\begin{array}{l}\text { Street traffic } \\
\text { (daily congestion) }\end{array}$ & $\$ 0.34$ per day to decrease travel delay by $1 \%$ \\
\hline $\begin{array}{l}\text { Krekel and Zerrahn } \\
\text { (2017) }\end{array}$ & Germany & Wind turbines & $\begin{array}{l}€ 258 \text { per year per affected household (upper-bound } \\
\text { estimate) }\end{array}$ \\
\hline $\begin{array}{l}\text { Brenig and Proeger } \\
(2018)\end{array}$ & Europe & Security & $\begin{array}{l}€ 14,923 \text { or about } 52 \% \text { of annual household income to } \\
\text { increase feelings of safety from "unsafe" to "safe" }\end{array}$ \\
\hline \multirow[t]{3}{*}{$\begin{array}{l}\text { Del Saz-Salazar et } \\
\text { al. (2017) }\end{array}$} & \multirow[t]{3}{*}{ Spain } & \multirow[t]{3}{*}{ Cultural goods } & $\begin{array}{l}\text { Implicit WTP of "importance" given by the respondent to } \\
\text { conservation and preservation of cultural heritage" is } \\
€ 43.41\end{array}$ \\
\hline & & & $\begin{array}{l}\text { Implicit WTP of whether respondent views the cultural } \\
\text { project as "beneficial" is } € 38.80\end{array}$ \\
\hline & & & $\begin{array}{l}\text { Implicit WTP of whether respondent views Cuenca } \\
\text { "distinct" from other cities in Spain }\end{array}$ \\
\hline
\end{tabular}

$\mathrm{LS}=$ life satisfaction, $\mathrm{m}=$ meter, $\mathrm{NO}_{2}=$ nitrogen dioxide, $\mathrm{OECD}=$ Organisation for Economic Co-operation and Development, $\mathrm{PM} \mathrm{M}_{10}=$ articulate matter of 10 micrometers or less, $\mathrm{SO}_{2}=$ sulfur dioxide, UK = United Kingdom of Great Britain and Northern Ireland, WTP = willingness to pay. Source: Compiled by authors from sources noted in the table; see the Reference section.

The use of Hicksian compensating variation based on the characterization of SWB has the potential to augment the tools used in the economic analysis of investments with nonmarket benefits. In particular, the method avoids problems of hypothetical bias and strategic reporting that plague the stated preference approaches, and it avoids endogenous relationships between amenity presence and market values that are often problematic in hedonic methods.

At the same time, the method has limitations. Exposure to public problems, such as flooding, is often not random. Problem exposure may condition property prices, so that the lowest cost property may be in the problem affected area, and the poorest population self-selects into problem exposure areas. As a result, problem exposure may be endogenous and multicollinear with income, so that it is not possible to recover unbiased coefficients with relation to LS (Dolan, Fujiwara, and Metcalfe 2011; Levinson 2018). Instrumentation may help in some cases to exogenize the problem, but instruments that have been reliably measured, satisfy the exclusion restriction, and are relevant are often difficult to find. 
The technique is thus most relevant in cases where problem exposure is most likely to be unrelated to income. However, for this to be the case, the problem may need to be infrequent or unpredictable, or property markets may need to be sufficiently distorted that problem effects are not priced into property values. At the same time, if a problem is infrequent or unpredictable, there may be difficulties with obtaining good data on problem occurrence. The technique is only relevant when the problem to be solved is substantial enough that it can be posited to have a significant effect on happiness.

Fixed effects LSA models that use panel data may help to drop out initial differences across populations and reduce endogeneity. They may also help address problems of habituation, or people adjusting to the presence of problems over the long term, so the victims no longer consider the situations as problems when responding to SWB questions. However, this approach also requires conducting panel surveys over periods with differing problem magnitudes or intensities, which is less common than simple cross-section or repeated cross-section analysis (Levinson 2018).

Each survey also depends on having a well-being indicator that has desired psychometric properties of reliability and validity for the respondent population, as well as interpersonal comparability. These properties may vary based on culture and presentation, and it may take time to refine the indicators so that the survey performance is sufficient for use in economic analysis. Insufficiently validated measures have been observed to have extreme sensitivity to short-term influences (Schwarz and Strack 1991), which can result in misleading results.

The technique depends on conducting a detailed set of surveys that can measure LS, problem exposure, income, other independent variables, and any instrument reliably and with a sample sufficient size for statistical power, considering correlations of observations within locations. As the income of poor and marginalized populations exposed to nonmarket problems is often diversified, informal, and reliant on own-account production, such as in agriculture, detailed large scale surveys are often required. Where problems and their effects are site specific, these detailed surveys will often need to be project specific.

As presented in equation (3), estimation of compensating surplus depends on the coefficients estimated for both income and the attribute to be valued. Estimation of the coefficient for income in LSA studies has been found to be problematic, with a downward bias frequently observed due to endogeneity and measurement error (Fujiwara and Campbell 2011). This downward bias, in turn, leads to overestimation of the valued attribute. Avoiding measurement error on income depends on having very carefully designed surveys, and panel data techniques may be needed to help solve endogeneity problems by controlling for time-invariant factors.

Finally, care is needed to reconcile the values generated with the services offered by a particular investment. For example, the case study presented illustrates compensating variation for elimination of all flood events, not the events that a particular investment eliminates (which are usually up to a specific average return period), and additional analysis is needed to understand external effects on communities downstream of flood control measures.

Considering these caveats, the technique has potential in situations where: i) problem or amenity exposure is not directly correlated with income, ii) problem or amenity exposure can be consistently measured, and iii) SWB measures have been developed and validated. As the LSA requires substantial numbers of observations and detailed data, it may be best applied where 
relationships between problems and compensating variation may be generalized for use in multiple economic analyses.

A particularly relevant application may be for health outcomes, for which conventional approaches to morbidity valuation often face challenges. Adverse effects on health, especially from pollution, often are not directly and inversely related to income, and the relationships between pollution exposure and well-being are likely to be stable and transferrable across locations. The technique may also have good potential for analyzing environmental amenities, such as forests and natural vegetation, in cases where the association between amenity presence and happiness is posited to be strong, but effects on property pricing are not substantial enough to create endogeneity concerns. For these types of amenities there is often no alternative to stated preference approaches.

\section{CONCLUSION}

Economic analysis of projects with nonmarket benefits often faces challenges, as each traditional approach has limitations. The Life Satisfaction Approach (LSA) offers an additional approach to the standard set of methods for nonmarket valuation by estimating Hicksian compensating variation using self-reported life satisfaction scores as approximation of utility. The LSA draws out estimates for income and changes in goods or services and then calculates the marginal rate of substitution of income.

This paper discusses the development of the LSA in the economics discipline and demonstrates its use in economic valuation using a case of floods in the Philippines. As one of the first LSA applications to the Philippines, and one of the few applications of the technique to natural disasters, the paper offers an innovative example. The LS model uses self-reported LS and selfreported flood damage incurred by households in monetizing flood prevention investments. The paper has shown that it is possible to determine the monetary value of flood prevention by looking at how the reduction of flood prevention affects well-being. It shows that there is a substantially greater effect on utility for flood-affected households than the direct level of losses that the households experience. This additional effect beyond direct losses may be difficult to capture via other means than the LSA, as it may relate to trauma and other suffering that is not captured in direct financial losses. Given the high risk that many developing Asian countries face from natural disasters and extreme climatic events under climate change, it is likely that similar additional impacts on well-being beyond financial losses may be faced in many situations. This paper suggests that LSA may have important potential to capture these values and inform consideration of disaster risk reduction investments.

The case presented illustrates that LSA is a complementary approach for economic valuation, that is less prone to hypothetical and strategic biases than stated preference approaches, such as contingent valuation (Levinson 2018). Although LSA has limitations, it offers an important alternative tool for valuation in specific investment situations where other techniques often face difficulties. Those situations include where (i) problem exposure is not directly and strongly conditioned by income, (ii) an indicator of well-being has been identified with the necessary psychometric properties for the respondent population, and (iii) it is possible to collect necessary data with sufficient detail and sample sizes in time to inform economic analysis and investment decisions. Under such conditions, the LSA provides a complement to other approaches for economic analysis of investments and other interventions. 
APPENDIX: Common Determinants of Individual Life Satisfaction

\begin{tabular}{|c|c|c|c|c|c|}
\hline $\begin{array}{l}\text { Natural } \\
\text { Capital }\end{array}$ & Social Capital & $\begin{array}{l}\text { Human or } \\
\text { Built Capital }\end{array}$ & $\begin{array}{c}\text { Environmental } \\
\text { Amenities }\end{array}$ & $\begin{array}{c}\text { Sociodemographic } \\
\text { Characteristics }\end{array}$ & $\begin{array}{l}\text { Other } \\
\text { Economic } \\
\text { Indicators }\end{array}$ \\
\hline $\begin{array}{l}\text { Natural } \\
\text { capital per } \\
\text { capita (Moro } \\
\text { et al. 2008) }\end{array}$ & $\begin{array}{l}\text { Participation } \\
\text { (consultation, } \\
\text { voluntary work, } \\
\text { etc.) (Schyns } \\
\text { 2002, Helliwel } \\
\text { 2003, Stanca } \\
\text { 2009) }\end{array}$ & $\begin{array}{l}\text { Employment } \\
\text { status (Di Tella, } \\
\text { MacCulloch, and } \\
\text { Oswald 2001; } \\
\text { Frey and Stutzer } \\
\text { 2002; Helliwel } \\
\text { 2003; Helliwell } \\
\text { 2006; Moro et al. } \\
\text { 2008; Arifwidodo } \\
\text { and Perera 2011) }\end{array}$ & $\begin{array}{l}\text { Temperature } \\
\text { (Blomquist, Berger, } \\
\text { and Hoehn 1988; } \\
\text { Frijters and van Praag } \\
\text { 1998; Rehdanz and } \\
\text { Maddison 2005; } \\
\text { Brereton, Clinch, and } \\
\text { Ferreira 2008; Moro } \\
\text { et al. 2008; Stanca } \\
\text { 2009; Maddison and } \\
\text { Rehdanz 2011) }\end{array}$ & $\begin{array}{l}\text { Age (Frijters and } \\
\text { van Praag 1998; } \\
\text { Schyns 2002; Di } \\
\text { Tella, MacCulloch, } \\
\text { and Oswald 2003; } \\
\text { Helliwel 2003; } \\
\text { Brereton, Clinch, } \\
\text { and Ferreira 2008; } \\
\text { Moro et al. 2008; } \\
\text { Stutzer and Frey } \\
\text { 2010) }\end{array}$ & $\begin{array}{l}\text { Unemployment } \\
\text { rate (Di Tella, } \\
\text { MacCulloch, } \\
\text { and Oswald } \\
\text { 2001; Rehdanz } \\
\text { and Maddison } \\
\text { 2005; Moro et } \\
\text { al. 2008; } \\
\text { Welsch 2008; } \\
\text { Stanca 2009) }\end{array}$ \\
\hline $\begin{array}{l}\text { Air pollution } \\
\text { (Welsch } \\
2002, \\
\text { Arifwidodo } \\
\text { and Perera } \\
2011 \text { ) }\end{array}$ & $\begin{array}{l}\text { Trust (Helliwell } \\
\text { 2006, Engelbrecht } \\
\text { 2009) }\end{array}$ & $\begin{array}{l}\text { Education } \\
\text { (Blomquist, } \\
\text { Berger, and } \\
\text { Hoehn 1988; } \\
\text { Frijters and van } \\
\text { Praag 1998; Frey } \\
\text { and Stutzer 2002; } \\
\text { Rehdanz and } \\
\text { Maddison 2005; } \\
\text { Brereton, Clinch, } \\
\text { and Ferreira } \\
\text { 2008; Moro et al. } \\
\text { 2008) }\end{array}$ & $\begin{array}{l}\text { Latitude - climate } \\
\text { (Blomquist, Berger, } \\
\text { and Hoehn 1988; } \\
\text { Brereton, Clinch, and } \\
\text { Ferreira 2008; Moro } \\
\text { et al. 2008; } \\
\text { Arifwidodo and } \\
\text { Perera 2011) }\end{array}$ & $\begin{array}{l}\text { Household and } \\
\text { individual income } \\
\text { (Frijters and van } \\
\text { Praag 1998; Schyns } \\
\text { 2002; Di Tella, } \\
\text { MacCulloch, and } \\
\text { Oswald 2003; } \\
\text { Helliwell 2006; } \\
\text { Brereton, Clinch, } \\
\text { and Ferreira 2008; } \\
\text { Stutzer and Frey } \\
\text { 2008) }\end{array}$ & $\begin{array}{l}\text { Income - gross } \\
\text { national income } \\
\text { per capita } \\
\text { (Welsch 2002; } \\
\text { Schyns 2002; } \\
\text { Rehdanz and } \\
\text { Maddison } \\
\text { 2005; Deaton, } \\
\text { Fortson, and } \\
\text { Tortora 2009; } \\
\text { Engelbrecht } \\
\text { 2009; Stanca } \\
\text { 2009; } \\
\text { Maddison and } \\
\text { Rehdanz 2011) }\end{array}$ \\
\hline \multirow[t]{2}{*}{$\begin{array}{l}\text { Ecosystem } \\
\text { services } \\
\text { product } \\
\text { (Vemuri and } \\
\text { Costanza } \\
\text { 2006; } \\
\text { Abdallah } \\
\text { Thompson, } \\
\text { and Marks } \\
\text { 2008) }\end{array}$} & $\begin{array}{l}\text { Friends or } \\
\text { neighbors or } \\
\text { community } \\
\text { (Stanca 2009, } \\
\text { Arifwidodo and } \\
\text { Perera 2011) }\end{array}$ & $\begin{array}{l}\text { Health (Helliwel } \\
\text { 2003; Abdallah } \\
\text { Thompson, and } \\
\text { Marks 2008; } \\
\text { Brereton, Clinch, } \\
\text { and Ferreira } \\
\text { 2008; Moro et al. } \\
\text { 2008; Welsch } \\
\text { 2008; Stanca } \\
\text { 2009) }\end{array}$ & $\begin{array}{l}\text { Pollution - waste } \\
\text { (Rehdanz and } \\
\text { Maddison 2005, } \\
\text { Moro et al. 2008, } \\
\text { Welsch 2008, } \\
\text { Stanca 2009, } \\
\text { Arifwidodo and } \\
\text { Perera 2011, } \\
\text { Maddison and } \\
\text { Rehdanz 2011) }\end{array}$ & $\begin{array}{l}\text { Gender (Frey and } \\
\text { Stutzer 2002; Di } \\
\text { Tella, MacCulloch, } \\
\text { and Oswald 2003; } \\
\text { Helliwell 2006; } \\
\text { Brereton, Clinch, } \\
\text { and Ferreira 2008; } \\
\text { Arifwidodo and } \\
\text { Perera 2011) }\end{array}$ & $\begin{array}{l}\text { Income } \\
\text { inequality } \\
\text { (Engelbrecht } \\
\text { 2009) }\end{array}$ \\
\hline & $\begin{array}{l}\text { Family (marital } \\
\text { status, relationship, } \\
\text { relatives abroad, } \\
\text { etc.) (Schyns } \\
\text { 2002; Helliwel } \\
\text { 2003; Helliwell } \\
\text { 2006; Brereton, } \\
\text { Clinch, and } \\
\text { Ferreira 2008; } \\
\text { Moro et al. 2008; } \\
\text { Arifwidodo and } \\
\text { Perera 2011) }\end{array}$ & $\begin{array}{l}\text { Human } \\
\text { Development } \\
\text { Index (Vemuri } \\
\text { and Costanza } \\
\text { 2006) }\end{array}$ & $\begin{array}{l}\text { Population density - } \\
\text { congestion (Frijters } \\
\text { and van Praag 1998; } \\
\text { Moro et al. 2008; } \\
\text { Abdallah, Thompson, } \\
\text { and Marks 2008; } \\
\text { Stanca 2009; } \\
\text { Arifwidodo and } \\
\text { Perera 2011) }\end{array}$ & $\begin{array}{l}\text { Family size and } \\
\text { dependents } \\
\text { (Frijters and van } \\
\text { Praag 1998; Frey } \\
\text { and Stutzer 2002; } \\
\text { Di Tella, } \\
\text { MacCulloch, and } \\
\text { Oswald 2003; } \\
\text { Brereton, Clinch, } \\
\text { and Ferreira 2008; } \\
\text { Moro et al. 2008; } \\
\text { Stutzer and Frey } \\
\text { 2008) }\end{array}$ & $\begin{array}{l}\text { Inflation rate } \\
\text { (Welsch 2008, } \\
\text { Stanca 2009, } \\
\text { Maddison and } \\
\text { Rehdanz 2011) }\end{array}$ \\
\hline
\end{tabular}




\begin{tabular}{|c|c|c|c|c|c|}
\hline $\begin{array}{l}\text { Natural } \\
\text { Capital }\end{array}$ & Social Capital & $\begin{array}{l}\text { Human or } \\
\text { Built Capital }\end{array}$ & $\begin{array}{c}\text { Environmental } \\
\text { Amenities }\end{array}$ & $\begin{array}{c}\text { Sociodemographic } \\
\text { Characteristics }\end{array}$ & $\begin{array}{c}\text { Other } \\
\text { Economic } \\
\text { Indicators }\end{array}$ \\
\hline & $\begin{array}{l}\text { Religion (Helliwel } \\
\text { 2003, Rehdanz } \\
\text { and Maddison } \\
\text { 2005, Helliwell } \\
\text { 2006, Stanca } \\
\text { 2009) }\end{array}$ & $\begin{array}{l}\text { Scientists and } \\
\text { engineers } \\
\text { (Maddison and } \\
\text { Rehdanz 2011) }\end{array}$ & $\begin{array}{l}\text { Urbanization } \\
\text { (Helliwel 2003, } \\
\text { Moro et al. 2008, } \\
\text { Stutzer and Frey } \\
\text { 2008, Arifwidodo } \\
\text { and Perera 2011) }\end{array}$ & $\begin{array}{l}\text { House type and } \\
\text { tenure (Brereton, } \\
\text { Clinch, and Ferreira } \\
\text { 2008; Moro et al. } \\
\text { 2008; Arifwidodo } \\
\text { and Perera 2011) }\end{array}$ & \\
\hline & $\begin{array}{l}\text { Crime rate and } \\
\text { security } \\
\text { (Blomquist, Berger, } \\
\text { and Hoehn 1988; } \\
\text { Brereton, Clinch, } \\
\text { and Ferreira 2008; } \\
\text { Arifwidodo and } \\
\text { Perera 2011) }\end{array}$ & $\begin{array}{l}\text { Infrastructure } \\
\text { (Brereton, Clinch, } \\
\text { and Ferreira } \\
\text { 2008; Arifwidodo } \\
\text { and Perera 2011) }\end{array}$ & $\begin{array}{l}\text { Location (Frey and } \\
\text { Stutzer 2002, } \\
\text { Brereton, Clinch, and } \\
\text { Ferreira 2008) }\end{array}$ & $\begin{array}{l}\text { Head of household } \\
\text { (Stutzer and Frey } \\
\text { 2008) }\end{array}$ & \\
\hline & $\begin{array}{l}\text { Institutional } \\
\text { variable - } \\
\text { governance (Frey } \\
\text { and Stutzer 2002, } \\
\text { Welsch 2002, } \\
\text { Rehdanz and } \\
\text { Maddison 2005; } \\
\text { Vemuri and } \\
\text { Costanza 2006, } \\
\text { Welsch 2008, } \\
\text { Engelbrecht 2009, } \\
\text { Stanca 2009, } \\
\text { Maddison and } \\
\text { Rehdanz 2011) }\end{array}$ & & & $\begin{array}{l}\text { Foreigner or local } \\
\text { (Frey and Stutzer } \\
\text { 2002) }\end{array}$ & \\
\hline & $\begin{array}{l}\text { Self-reported } \\
\text { honesty (Helliwel } \\
\text { 2003) }\end{array}$ & & & $\begin{array}{l}\text { Health (Okun and } \\
\text { George 1984; } \\
\text { Veenhoven 1991; } \\
\text { Helliwel 2003; } \\
\text { Ferrer-i-Carbonell } \\
\text { and Frijters 2004; } \\
\text { He, Shi, and Yi } \\
\text { 2014) }\end{array}$ & \\
\hline
\end{tabular}

Source: Fernandez (2016, p. 52). 


\section{REFERENCES}

Abdallah, Saamah, Sam Thompson, and Nic Marks. 2008. "Estimating Worldwide Life Satisfaction." Ecological Economics 65 (1): 35-47.

Ambrey, Christopher, and Christopher Fleming. 2014. "Public Greenspace and Life Satisfaction in Urban Australia.” Urban Studies 51 (6): 1290-321.

Anderson, Michael, Fangwen Lu, Yiran Zhang, Jun Yang, and Ping Qin. 2016. "Superstitions, Street Traffic, and Subjective Well-Being." Journal of Public Economics 142: 1-10.

Arifwidodo, Sigit Dwiananto, and Ranjith Perera. 2011. "Quality of Life and Compact Development Policies in Bandung, Indonesia." Applied Research in Quality of Life 6 (2): 159-79.

Aristotle. 1980. Nicomachean Ethics. Oxford: Oxford University Press.

Asian Development Bank (ADB). 2017. Guidelines for the Economic Analysis of Projects. Manila.

Benthham, Jeremy. 1970 (1780). Introduction to the Principles of Morals and Legislation. In Collected Works of Jeremy Bentham, edited by J. H. Burns and H. L. Hart. London: Athlone. http://la.utexas.edu/users/hcleaver/368/368BenthamCh1table.pdf (accessed 19 January 2018).

1983 (1834). "Deontology." In Deontology Together with the Springs of Action, edited by A. Goldworth. Oxford: Clarendon.

Blanchflower, David, and Andrew Oswald. 2004. "Well-Being over Time in Britain and the USA." Journal of Public Economics 88 (7): 1359-86.

Blomquist,Glenn, Mark Berger, and John Hoehn. 1988. "New Estimates of Quality of Life in Urban Areas.” American Economic Review 78 (1): 89-107.

Botzen, Wouter, Jeroen Aerts, and Jeroen Van den Bergh. 2013. "Individual Preferences for Reducing Flood Risk to Near Zero through Elevation." Mitigation and Adaptation Strategies for Global Change 18 (2): 229-44.

Brenig, Mattheus, and Till Proeger. 2018. "Putting a Price Tag on Security: Subjective Well-Being and Willingness-to-Pay for Crime Reduction in Europe." Journal of Happiness Studies 19 (1): 145-66.

Brereton, Finbarr, J Peter Clinch, and Susanna Ferreira. 2008. "Happiness, Geography and the Environment." Ecological Economics 65 (2): 386-96.

Brouwer, Roy, Sonia Akter, Luke Brander, and Enamul Haque. 2009. "Economic Valuation of Flood Risk Exposure and Reduction in a Severely Flood Prone Developing Country." Environment and Development Economics 14 (3): 392-417.

Bruni, Luigino. 2010. "The Happiness of Sociality. Economics and Eudaimonia: A Necessary Encounter." Rationality and Society 22 (4): 383-406. 
Bui, Duc Tinh, and Manh Hung Nguyen. 2014. "Modelling Demand for Catastrophic Flood IndexBased Insurance in Da Nang City, Viet Nam: Using Choice Experiments." Working Paper Series 10. Asian Cities Climate Resilience.

Carroll, Nick, Paul Frijters, and Michael Shields. 2009. "Quantifying the Costs of Drought: New Evidence from Life Satisfaction." Journal of Population Economics 22 (2): 445-61.

Cha, Eun Jeong, and Bruce Ellingwood. 2012. "Risk-Averse Decision-Making for Civil Infrastructure Exposed to Low-Probability, High-Consequence Events.” Reliability Engineering \& System Safety 104: 27-35.

Clark, Andrew, and Andrew Oswald. 1994. "Unhappiness and Unemployment." The Economic Journal 104 (242): 648-59.

Collard, David. 2006. "Research on Well-Being. Some Advice from Jeremy Bentham." Philosophy of Social Sciences 36 (3): 330-54.

Cramm, J. M., Valerie Møller, and Anna Nieboer. 2012. "Individual- and Neighbourhood-Level Indicators of Subjective Well-Being in a Small and Poor Eastern Cape Township: The Effect of Health, Social Capital, Marital Status, and Income." Social Indicators Research 105 (3): 581-93.

D'Acci, Luca. 2011. “Measuring Well-Being and Progress.” Social Indicators Research 104 (1): 47-65.

Deaton, Angus, Jane Fortson, and Robert Tortora. 2009. "Life (Evaluation), HIV/AIDS, and Death in Africa." NBER Working Paper No. 14637.

Del Saz-Salazar, Salvador, Anna Navarrete-Tudela, Jose Alcala-Mellado, and Daniel Carlos del SazSalazar. 2017. "On the Use of Life Satisfaction Data for Valuing Cultural Goods: A First Attempt and a Comparison with the Contingent Valuation Method." Journal of Happiness Studies. https://doi.org/10.1007/s10902-017-9942-2.

Di Tella, Rafael, Robert MacCulloch, and Andrew Oswald. 2001. "Preferences Over Inflation and Unemployment: Evidence from Surveys of Happiness." American Economic Review 91 (1): 335-41.

2003. "The Macroeconomics of Happiness." The Review of Economics and Statistics 85 (4): 809-27.

Diener, Ed. 2006. "Guidelines for National Indicators of Subjective Well-Being and III-Being. Journal of Happiness Studies 7 (4): 397-404.

Diener, Ed, Marissa Diener, and Carol Diener. 1995. "Factors Predicting the Subjective Well-Being of Nations." Journal of Personality and Social Psychology 69 (5): 851.

Diener, Ed, Ronald Inglehart, and Louis Tay. 2013. "Theory and Validity of Life Satisfaction Scales." Social Indicators Research 112 (3): 497-527.

Diener, Ed, Shigehiro Oishi, and Richard Lucas. 2003. "Personality, Culture, and Subjective Well-Being: Emotional and Cognitive Evaluations of Life.” Annual Review of Psychology 54 (1): 403-25.

Diener, Ed, Eunkook M Suh, Richard Lucas, and Heidi Smith. 1999. "Subjective Well-Being: Three Decades of Progress." Psychologial Bulletin 125 (2): 276-302. 
Dolan, Paul, Daniel Fujiwara, and Robert Metcalfe. 2011. "A Step towards Valuing Utility the Marginal and Cardinal Way.” CEP Discussion Paper No 1062.

Dolan, Paul, and Robert Metcalfe. 2008. "Comparing Willingness-to-Pay and Subjective Well-Being in the Context of Non-Market Goods." CEP Discussion Paper No 890.

Dolan, Paul, Tessa Peasgood, and Mathew White. 2008. "Do We Really Know What Makes Us Happy? A Review of the Economic Literature on the Factors Associated with Subjective WellBeing." Journal of Economic Psychology 29 (1): 94-122.

Dolan, Paul, and Matthew White. 2007. "How Can Measures of Subjective Well-Being Be Used to Inform Public Policy?” Perspective on Psychological Science 2 (1): 71-85.

Easterlin, Richard. 1974. "Does Economic Growth Improve the Human Lot? Some Empirical Evidence.” In Nations and Households in Economic Growth: Essays in Honor of Moses Abramowitz, edited by P. David and M. Warren. New York: Academic Press.

—. 1995. "Will Raising the Incomes of All Increase the Happiness of All?" Journal of Economic Behavior \& Organization 27 (1): 35-47.

Eid, Michael, and Ed Diener. 2004. "Global Judgments of Subjective Well-Being: Situational Variability and Long-Term Stability." Social Indicators Research 65 (3): 245-77.

Engelbrecht, Hans-jürgen. 2009. "Natural Capital, Subjective Well-Being, and the New Welfare Economics of Sustainability: Some Evidence from Cross-Country Regressions." Ecological Economics 69 (2): 380-88.

Fergusson, David, Geraldine McLeod, L. John Horwood, Nicola Swain, Simon Chapple, and R. Paulton. 2015. "Life Satisfaction and Mental Health Problems (18 to 35 years)." Psychological Medicine 45 (11): 2427-36.

Fernandez, Cheryl Joy. 2016. Methods for Determining How Much to Spend on Flood Prevention: An Empirical Case Study in the Philippines. PhD thesis, James Cook University, Australia.

Ferreira, Susana, Alpaslan Akay, Finbarr Brereton, Juncal Cuñado, Peter Martinsson, Mirko Moro, and Tine F. Ningal. 2013. “Life Satisfaction and Air Quality in Europe." Ecological Economics 88: 1-10.

Ferreira, Susana, and Mirko Moro. 2010. "On the Use of Subjective Well-Being Data for Environmental Valuation.” Environment Resource Economics 46 (3): 249-73.

Ferrer-i-Carbonell, Ada, and Paul Frijters. 2004. "How Important is Methodology for the Estimates of the Determinants of Happiness?" The Economic Journal 114 (497): 641-59.

Frey, Bruno, and Alois Stutzer. 2002. "What Can Economists Learn from Happiness Research?" Journal of Economic Literature 40 (2): 402-35.

Frey, Bruno, Simon Luechinger, and Alois Stutzer. 2009. "The Life Satisfaction Approach to Valuing Public Goods: The Case of Terrorism.” Public Choice 138 (3/4): 317-45. 
Frijters, Paul, and Bernard van Praag. 1998. "The Effects of Climate on Welfare and Well-Being in Russia." Climatic Change 39 (1): 61-81.

Fujiwara, Daniel, and Ross Campbell. 2011. Valuation Techniques for Social Cost-Benefit Analysis: Stated Preference, Revealed Preference, and Subjective Well-Being Approaches. A Discussion of Current Issues. London: HM Treasury.

Galinha, Iolanda C., and Jose Luis Pais-Ribeiro. 2011. "Cognitive, Affective and Contextual Predictors of Subjective Wellbeing." International Journal of Wellbeing 2 (1): 34-53.

Garcia, Danilo, Elisabetta Sagone, Maria Elvira de Caroli, and Ali Al Lima. 2017. "Italian and Swedish Adolescents: Differences and Associations in Subjective Well-Being and Psychological WellBeing." PeerJ 5: e2868.

Gong, Cathy, Rebecca Cassells, and Marcia Keegan. 2011. "Understanding the Life Satisfaction and Education Puzzle in Australia: A Profile from HILDA Wave 9.” National Centre for Social and Economic Modelling Working Paper 11/12.

Grothmann, Torsten, and Anthony Patt. 2005. "Adaptive Capacity and Human Cognition: The Process of Individual Adaptation to Climate Change." Global Environmental Change 15 (3):199-213.

He, Dan, Mei Shi, and Fang Yi. 2014. "Mediating Effects of Affect and Loneliness on the Relationship between Core Self-Evaluation and Life Satisfaction among Two Groups of Chinese Adolescents." Social Indicators Research 119 (2): 747-56.

Helliwell, John. 2003. "How's Life? Combining Individual and National Variables to Explain Subjective Well-Being." Economic Modelling 20 (2): 331-60.

2006. "Well-Being, Social Capital and Public Policy: What's New?" The Economic Journal 116 (510): C34-C45.

Helliwell, John, and Robert Putnam. 2004. "The Social Context of Well-Being." Philosophical Transactions of the Royal Society of London. Series B, Biological Sciences 359 (1449): 1435-46.

Hicks, John. 1939. Value and Capital: An Inquiry into Some Fundamental Principles of Economic Theory. Oxford: Clarendon Press.

Hurka, Thomas. 1993. Ethics and Climate Change: The Greenhouse Effect. Ontario, Canada: Wilfred Laurier University Press.

Johnson, Freddie L., Martha Foxall, Elizabeth Kelleher, Elizabeth Kentopp, Elizabeth Mannlein, and Ernestine Cook. 1988. "Comparison of Mental Health and Life Satisfaction of Five Elderly Ethnic Groups.” Western Journal of Nursing Research 10 (5): 613-28.

Jovanović, Veljko. 2016. "The Validity of the Satisfaction with Life Scale in Adolescents and a Comparison with Single-Item Life Satisfaction Measures: A Preliminary Study." Quality of Life Research 25 (12): 3173-80. 
Kahneman, Daniel. 1999. "Objective Happiness.” In Well-Being: the Foundations of Hedonic Psychology, edited by Daniel Kahneman, Ed Diener, and Norbert Schwartz. New York: Russell Sage Foundation.

Kahneman, Daniel, and Alan Krueger. 2006. "Developments in the Measurement of Subjective WellBeing." Journal of Economic Perspectives 20 (1): 3-24.

Kahneman, Daniel, Alan Krueger, David Schkade, Nobert Schwarz, and Arthur Stone. 2004. "A Survey Method of Characterizing Daily Life Experience: The Day Reconstruction Method." Science 306 (5702): 1776-80.

Kahneman, Daniel, and Jason Riis. 2005. "Living, and Thinking about It: Two Perspectives on Life." In The Science of Well-Being, edited by Felicia A. Huppert, Nick Baylis, and Barry Keverne. Oxford: Oxford University Press.

Kahneman, Daniel, Peter Wakker, and Rakesh Sarin. 1997. "Back to Bentham? Explorations of Experienced Utility." The Quarterly Journal of Economics 112 (2): 375-405.

Kountouris, Yiannis, and Kyriaki Remoundou. 2011. "Valuing the Welfare Cost of Forest Fires: A Life Satisfaction Approach.” Kyklos. 64 (4): 556-78.

Krekel, Christian, and Alexander Zerrahn. 2017. "Does the Presence of Wind Turbines have Negative Externalities for People in their Surroundings? Evidence from Well-Being Data." Journal of Environmental Economics and Management 82: 221-38.

Kristoffersen, Inga. 2010. "The Metrics of Subjective Well-Being: Cardinality, Neutrality, and Additivity.” Economic Record 86 (272): 98-123.

Kuehnle, Daniel, and Christoph Wunder. 2016. "Using the Life Satisfaction Approach to Value Daylight Savings Time Transitions: Evidence from Britain and Germany.” Journal of Happiness Studies 17 (6): 2293-323.

Lamond, Jessica, David Proverbs, and Felix Hammond. 2009. "Accessibility of Flood Risk Insurance in the UK: Confusion, Competition and Complacency." Journal of Risk Research 12 (6): 825-41.

Lazarus, Richard, and Susan Folkman. 1984. Stress, Appraisal, and Coping. Springer.

Levinson, Arik. 2018. "Happiness and Air Pollution." In Handbook on Well-Being, Happiness, and the Environment, edited by David Maddison, Katrin Rehdanz, and Heinz Welsch. Unpublished draft.

Lim, Hector, Ma. Bernadeth Lim, and Mongkut Piantanakulchai. 2016. "Determinants of Household Flood Evacuation Mode Choice in a Developing Country." Natural Hazards 84 (1): 507-32.

Linley, P. Alex, and Joseph Stephen. 2004. "Positive Change Following Trauma and Adversity: A Review." Journal of Traumatic Stress 17 (1): 11-21.

Luechinger, Simon. 2009. "Valuing Air Quality Using the Life Satisfaction Approach.” Economic Journal Conference Papers 119 (536): 482-515. 
Luechinger, Simon, and Paul Raschky. 2009. "Valuing Flood Disasters Using the Life Satisfaction Approach.” Journal of Public Economics 93 (3-4): 620-33.

MacKerron, George. 2012. “Happiness Economics from 35000 Feet.” Journal of Economic Surveys 26 (4): 705-35.

MacKerron, George, and Susana Mourato. 2009. "Life Satisfaction and Air Quality in London." Ecological Economics 68 (5): 1441-53.

Maddison, David, and Katrin Rehdanz. 2011. "The Impact of Climate on Life Satisfaction. Ecological Economics 70 (12): 2437-45.

Marshall, Alfred. 1920. Principles of Economics, $8^{\text {th }}$ Ed. London: Macmillan and Co. http://files.libertyfund.org/files/1676/Marshall_0197_EBk_v6.0.pdf (accessed 15 January 2018).

Matthieu, Monica, and Andre Ivanoff. 2006. "Using Stress, Appraisal, and Coping Theories in Clinical Practice: Assessments of Coping Strategies after Disasters." Brief Treatment and Crisis Intervention 6 (4): 337-48.

McMillen, J. Curtis, Elizabeth Smith, and Rachel Fisher. 1997. "Perceived Benefit and Mental Health after Three Types of Disaster." Journal of Consulting and Clinical Psychology 65 (5): 733-39.

Menz, Tobias, and Heinz Welsch. 2010. "Population Ageing and Environmental Preferences in OECD Countries: The Case of Air Pollution.” Ecological Economics 69 (12): 2582-89.

Moulton, Brent. 1990. "An Illustration of a Pitfall in Estimating the Effects of Aggregate Variables on Micro Units." The Review of Economics and Statistics 72 (2): 334-38.

Moro, Mirko, Finbarr Brereton, Susana Ferreira, and J. Peter Clinch. 2008. "Ranking Quality of Life Using Subjective Well-Being." Ecological Economics 65 (3): 448-60.

Murphy, James, Thomas Stevens, P. Geoffrey Allen, and Darryl Weatherhead. 2003. "A Meta-Analysis of Hypothetical Bias in Stated Preference Valuation." Department of Resource Economics, University of Massachusetts Working Paper No. 2003-8.

Okun, Morris, and Linda George. 1984. "Physician-and Self-Ratings of Health, Neuroticism, and Subjective Well-Being among Men and Women." Personality and Individual Differences 5 (5): 533-39.

Oulahen, Greg. 2015. "Flood Insurance in Canada: Implications for Flood Management and Residential Vulnerability to Flood Hazards." Environmental Management 55 (3): 603-15.

Park, Crystal. 2010. "Making Sense of the Meaning Literature: An Integrative Review of Meaning Making and Its Effects on Adjustment to Stressful Life Events." Psychological Bulletin 136 (2): 257-301.

Park, Crystal, and Vicki S. Helgeson. 2006. "Introduction to the Special Section: Growth Following Highly Stressful Life Events--Current Status and Future Directions.” Journal of Consulting and Clinical Psychology 74 (5): 791-96. 
Pavot, William, and Ed Diener. 1993. "Review of the Satisfaction with Life Scale." Psychological Assessment 5 (2): 164-72.

Rehdanz, Katrin, and David Maddison. 2005. “Climate and Happiness.” Ecological Economics 52 (1): 111-25.

Ryff, Carol. 1989. "Adult Personality Development and Motivation for Personal Growth." In Advances in Motivation and Achievement: Motivation and Adulthood, edited by Douglas A. Kleiber and Martin L. Maehr. Greenwich, CT: JAI Press.

Ryff, Carol, and Corey Lee Keyes. 1995. "The Structure of Psychological Well-Being Revisited.” Journal of Personality and Social Psychology 69 (4): 719-27.

Sandvik, Ed, Ed Diener, and Larry Seidlitz. 1993. "Subjective Well-Being: The Convergence and Stability of Self-Report and Non-Self-Report Measures.” Journal of Personality 61(3): 317-42.

Santos, Cristina. 2013. "Costs of Domestic Violence: A Life Satisfaction Approach.” Fiscal Studies 34 (3): 391-409.

Sarracino, Francesco. 2013. "Determinants of Subjective Well-Being in High and Low Income Countries: Do Happiness Equations Differ across Countries?" Journal of Socio-Economics 42 (C): 51-66.

Schwarz, Norbert, and Fritz. Strack. 1991. "Evaluating One's Life: A Judgment Model of Subjective Well-Being." In Subjective Well-Being: An Interdisciplinary Perspective, edited by Fritz Strack, Michael Argyle, and Norbert Schwarz. Oxford: Pergamon Press.

Schyns, Peggy. 2002. "Wealth of Nations, Individual Income and Life Satisfaction in 42 Countries: A Multilevel Approach.” Social Indicators Research 60 (1): 5-40.

Seligman, Martin, and Mihaly Csikszentmihalyi. 2014. Positive Psychology: An Introduction. Flow and the Foundations of Positive Psychology. Springer Netherlands.

Sheppard, Stephen Charles. 1998. "Hedonic Analysis of Housing Markets." Handbook of Regional and Urban Economics 3: 1595-635.

Stanca, Luca. 2009. "With or Without You? Measuring the Quality of Relational Life Throughout the World." Journal of Socio-Economics 38 (5): 834-42.

Steptoe, Andrew, Tessa Pollard, and Jane Wardle. 1995. "Development of a Measure of the Motives Underlying the Selection of Food: The Food Choice Questionnaire.” Appetite. 25 (3): 267-84.

Stutzer, Alois, and Bruno Frey. 2008. "Stress that Doesn't Pay: The Commuting Paradox?" Scandinavian Journal of Economics 110 (2): 339-66.

- 2010. "Recent Advances in the Economics of Individual Subjective Well-Being." Social Research 77 (2): 679-714.

Terano, Rika, and Zainalabidin Mohamed. 2014. "Life Satisfaction among Farmers in Paddy Granaries in Malaysia." Asian Social Science 10 (2): 229-35. 
Tsurumi, Tetsuya, and Shunsuke Managi. 2015. "Environmental Value of Green Spaces in Japan: An Application of Life Satisfaction Approach.” Ecological Economics 120: 1-12.

Tugade, Michele, Barbara Fredrickson, and Lisa Feldman Barrett. 2004. "Psychological Resilience and Positive Emotional Granularity: Examining the Benefits of Positive Emotions on Coping and Health." Journal of Personality 72 (6): 1161-90.

United Nations University Institute for Environment and Human Security (UNU-EHS). 2014. World Risk Report. Bonn, Germany.

van der Veen, Anne. 2004. "Disasters and Economic Damage: Macro Meso and Micro Approaches." Disaster Prevention and Management 13 (4): 274-79.

van Praag, Bernard, and Barbara Baarsma. 2005. 'Using Happiness Surveys to Value Intangibles: The Case of Airport Noise.” Economic Journal 115 (500): 224-46.

Veenhoven, Ruut. 1991. “Is Happiness Relative?” Social Indicators Research 24 (1):1-34.

—. 1995. "World Database of Happiness." Social Indicators of Research 34 (3): 299-313.

- 2014. World Database of Happiness Erasmus University Rotterdam. Retrieved from http://worlddatabaseofhappiness.eur.nl.

Vemuri, Amanda, and Robert Costanza. 2006. "The Role of Human, Social, Built, and Natural Capital in Explaining Life Satisfaction at the Country Level: Toward a National Well-Being Index (NWI)." Ecological Economics 58 (1): 119-33.

Walch, Colin. 2018. "Evacuation ahead of Natural Disasters: Evidence from Cyclone Phailin in India and Typhoon Haiyan in the Philippines." Geo: Geography and Environment. 5 (1): 1-16.

Welsch, Heinz. 2002. "Preferences over Prosperity and Pollution: Environmental Valuation Based on Happiness Surveys.” Kyklos 55 (4): 473-94.

- 2006. "Environment and Happiness: Valuation of Air Pollution Using Life Satisfaction Data." Ecological Economics 58 (4): 801-13.

_ 2008. "The Social Costs of Civil Conflict: Evidence from Surveys of Happiness." Kyklos 61 (2): 320-40.

Welsch, Heinz, and Philipp Biermann. 2014. "Electricity Supply Preferences in Europe: Evidence from Subjective Well-Being Data." Resource and Energy Economics 38: 38-60.

White, Mathew, and Paul Dolan. 2009. "Accounting for the Richness of Daily Activities." Psychological Science 20 (8): 1000-8. 


\section{Potential Use of the Life Satisfaction Approach to Value Nonmarket Goods and Services}

This paper explains the life satisfaction approach to economic analysis and illustrates it with an example of flooding from lloilo, Philippines. Recommendations are offered for application of the technique in the economic analysis of investment projects. The approach estimates Hicksian compensating variation using self-reported subjective well-being to calculate the marginal rate of substitution of income for nonmarket amenities or services.

\section{About the Asian Development Bank}

ADB is committed to achieving a prosperous, inclusive, resilient, and sustainable Asia and the Pacific, while sustaining its efforts to eradicate extreme poverty. Established in 1966, it is owned by 67 members48 from the region. Its main instruments for helping its developing member countries are policy dialogue, loans, equity investments, guarantees, grants, and technical assistance. 